which is intended to be used in place of the Ringelmann ehart. Those familiar with the Ringelmann method will recognize that it has never proved to be a really satisfactory means of assessing smoke pollution. In principle, the new instrument consists of a small telescope containing a number of translucent screens, darkened to standard shades, with which the smoke can be compared. The instrument is held so that the screens are seen against the same background as the smoke. It is easy to read, and consistont observations are obtained by different observers.

Another problem which has been investigated is the emission of exhaust gases from motor-vehicles, a nuisance familiar alike to motorist and pedestrian. In this case the effectiveness of a catalytic combustion unit has been examined and found to reduce substantially the concentration of carbon monoxide in the exhaust gas. The life of the catalyst, however, as would be suspected, is a limiting factor of usefulness, signs of deterioration having been shown after 11,000 miles.

There is an impression on the lay mind, arising perhaps from the magic associated with the development of nuclear energy, that a new scientific sun has arisen which will put out the candle of coal. As yet it may be wishful thinking. Our coalfields are still of great importance to Great Britain, and this situation must yet remain for a long time. Accordingly, the reference in the report to the continuation of work on the synthesis of oil from coal should be regarded as a timely reminder of the problems ahead. With the development of nuclear energy, the rapid spread both domestically and industrially in the use of oil, and the foreshadowed increase in the application of oil to the making of towns' gas, it is not possible to envisage a future surplus of low-grade coal of the kind now consumed by power stations. The total gasification of such coal into gaseous fuels suitable for distribution or for synthetic purposes is a matter to which serious attention should be given. It will need national support on a far more substantial scale than has been applied in the past. By this means alone can the sulphur problem in atmospherie pollution be solved. The reduction in the consumption of coal may before long become a major issue in fuel policy. We are approaching the situation in which we may see even remunerative collieries shut down, while at the same time attempting to sell exports in a highly competitive market in order to pay for imported fuels that have replaced the use of coal.

This statement may well be regarded as controversial, but to envisage the possibility is to take stock of the remedy. There is accordingly no less urgency in fuel research than there was when the Fuel Research Station at Greenwich was established in 1917, for as the field of activity has extended the problems have multiplied. In this way alone does technological advancement, so much needed in a modern world, take place.

\title{
THE METROPOLITAN WATER BOARD
}

\section{REPORT FOR 1955-56}

T HE Metropolitan Water Board now distributes 322 million gallons of water daily, taking its raw supplies both from rivers and wells, treating them by $a$ wide variety of processes and carrying out very extensive chemical, bacteriological and biological research to develop new methods of treatment and control and to maintain the safety and palatability of the finished product. The reports of the Director of Water Examination always contain a detailed and well-documented account of the quality control, and research, for which he is responsible. A large part of the bacteriological section of the present report* is concerned with the enumeration of bacteria, particularly of coliforms, by the method of multiple tubes and by membrane filtration. It has been shown that the membrane filtration technique is superior for the examination of some, but not all, types of water ; it is, for example, now used as the standard method for the routine examination of all stored waters. It has been found that the membranes, which are somewhat expensive, can be re-used several times, and it seems possible that the method may eventually prove to be much cheaper in materials than the multiple tube technique previously employed. Another very useful piece of work described in this part of the report deals with the standardization and selection of bile salts and peptone-different samples of which differ considerably in their properties in the MacConkey test.

The biological section of the report is concerned mainly with the control of the growth of planktonic

* Metropolitan Water Board. Thirty-seventh Report”on the Results of the Bacteriological, Chemical and Biological Examination of the London Waters for the years 1955-1956. By E. Windle Taylor. Pp.
$112+7$ plates. (London: Metropolitan Water Board, 1958.) 21s. algae in reservoirs. A constant check is made of the numbers of these at different depths and of the concentration of nutrient substances in the water, and from this information the counter-measures to be used to prevent interference with the treatment plants are decided. It is sometimes possible to avoid trouble by altering the depth at which water is drawn from a reservoir ; sometimes copper sulphate is added, though this always involves a considerable risk of failure and usually requires calm weather to be successful ; and it is still necessary at times to take a reservoir out of service until an outburst of algae has died down. Hydrographic studies on the King George VI reservoir, together with experiments with models made in conjunction with the University of London, have suggested that the difficulties caused by thermal stratification, which limit the allowable depth, may not be so serious as had been thought and that it might be practicable and economic to induce vertical circulation of the water by pumping or by careful design of inlets. A differential temperature recorder for varying thermal stratification has been developed and has bcen tested in the field.

There is a further account of research on the sterilization of juto yarn, which is used for packing joints between pipes. It is now suggested that the yarn might be sterilized by the vapour of formaldehyde, being then treated with copper sulphate, iron alum, and sodium carbonate to prevent rotting.

A long section of the report deals with comparative tests with several large experimental plants (both upward-flow and horizontal-flow) on the clarification of water after coagulation with alum and activated 
silica; the effect of treatmient on the filterability, bacterial count, chemical composition, and numbers of invertebrates and algae, has been studied in great detail. From results of large-scale experiments it is believed that it would be economic to recover alum for re-use from the sludge by drying it, calcining and treating with sulphuric acid.

The present report includes an index of the thirtieth to the thirty-seventh reports (1935-56).

\title{
YIELD OF INFECTIVE 'RIBONUCLEIC ACID' FROM IMPURE MURRAY VALLEY ENCEPHALITIS VIRUS AFTER DIFFERENT TREATMENTS
}

\author{
By G. L. ADA and S. G. ANDERSON \\ Walter and Eliza $\mathrm{H} a l l$ Institute of Medical Research, Melbourne
}

$\mathrm{F}^{\circ}$ OLLOWING the procedure of Gierer and Schramm, we have prepared an infective product by phenol treatment of erude suspensions of Murray Valley encephalitis virus from baby mouse brains. The infectivity of this product was destroyed by pancreatic ribonuclease (Worthington) and by normal rabbit serum, but in saline was more stable than virus. It seems that this product is essentially ribonucleic acid, although it probably contains other substances also. Following the practice of other workers', we have designated the product 'RNA'. For titration, virus has been diluted in 10 per cent normal rabbit serum in saline, and ' $\mathrm{RNA}$ ' has been diluted in a phosphate citrate buffered saline at $p \mathrm{H} 7 \cdot 1$. Chick embryos 12 days old were inoculated on the chorioallantoic membrane with $0.05 \mathrm{ml}$. vol., and the lethal end-points were determined at 3 days.

In most respects, the 'RNA' of Murray Valley encephalitis virus behaved like the 'RNA' of other viruses recently reported. But in addition it was found possible to recover infective ' $R N A$ ' from crude virus which had been treated in various ways designed to reduce its infectivity considerably.

When crude virus with a titre of $10^{6.7}$ was treated with 9 per cent phenol for 1 min., the resulting suspension had no infectivity. After subsequent treatment of this suspension with 90 per cent phenol, as

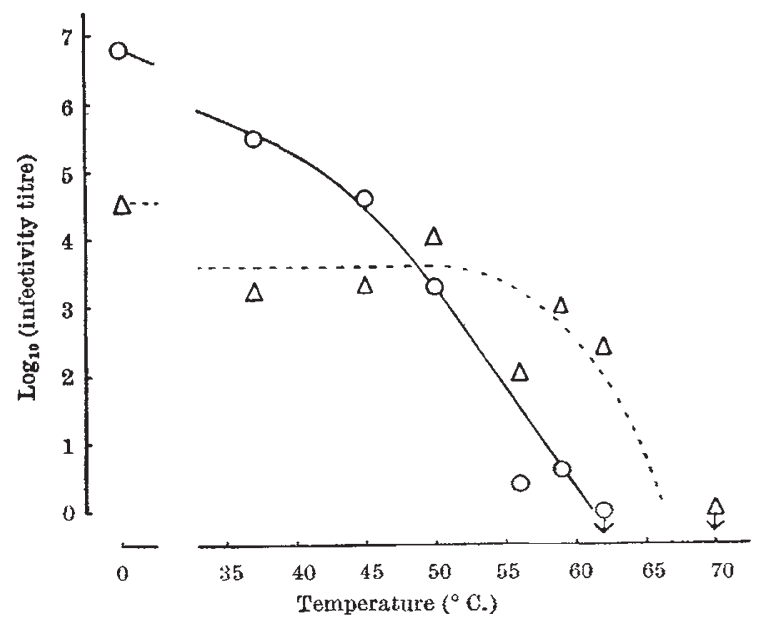

Fig. 1. Infectivity titres for the chick embryo of crude preparations of Murray Valley encephalitis virus heated for $60 \mathrm{~min}$. at different temperatures and of the ' $R N A$ ' derived by phenol treatment from such heated virus

$O$, infectivity of heated virus; $\Delta$, infectivity of ribonucleic acid derived from heated virus in the standard method of Gierer and Schramm, infective 'RNA' appeared and reached a titre of $10^{4}-10^{5}$ by the end of the extraction procedure.

Crude Murray Valley encephalitis virus lost infectivity on heating; for example, original virus with a titre of $10^{2}$ was reduced in titre to $10^{1.0}$ by holding at $56^{\circ} \mathrm{C}$. and $p \mathrm{H} 7 \cdot 1$ for $60 \mathrm{~min}$. ; and after holding at $62^{\circ} \mathrm{C}$. for $60 \mathrm{~min}$. the undiluted preparation failed to infect chick embryos. The standard phenol procedure was applied to both these heated preparations and yielded samples of 'RNA' with infective titres of $10^{2.0}$ and $10^{2.7}$, respectively. These latter infectivities were lost on incubation with $1 \mu \mathrm{gm} . / \mathrm{ml}$. of ribonuclease for $20 \mathrm{~min}$. at $15^{\circ} \mathrm{C}$. A series of results of this type is shown graphically in Fig. 1. The normal ratio of titre of original crude virus to titre of ' $\mathrm{RNA}$ ' derived from this virus was usually about $1^{2}$ as titrated in eggs. For virus heated at or above $50^{\circ} \mathrm{C}$. for $60 \mathrm{~min}$. this ratio became less than 1 .

Throughout the present work all titrations of infectivity were carried out in chick embryos, but it may be noted that if infectivities were titrated by inoculation of baby mice by the intracerebral route, normal virus titred at $10^{8.2}$ and ' $R N A$ ' derived from it, at $10^{2.8} L D 50$ per $0.01 \mathrm{ml}$. This $V / R$ ratio $\left(10^{8.2} / 10^{2.8}\right)$ fell to $10^{2.7} / 10^{0.5}$ for virus heated at $62^{\circ} \mathrm{C}$.

Virus lost titre at a low $p H$. After standing at $p \mathrm{H} 3.0$ for $30 \mathrm{~min}$. at $20^{\circ} \mathrm{C}$, a crude preparation of

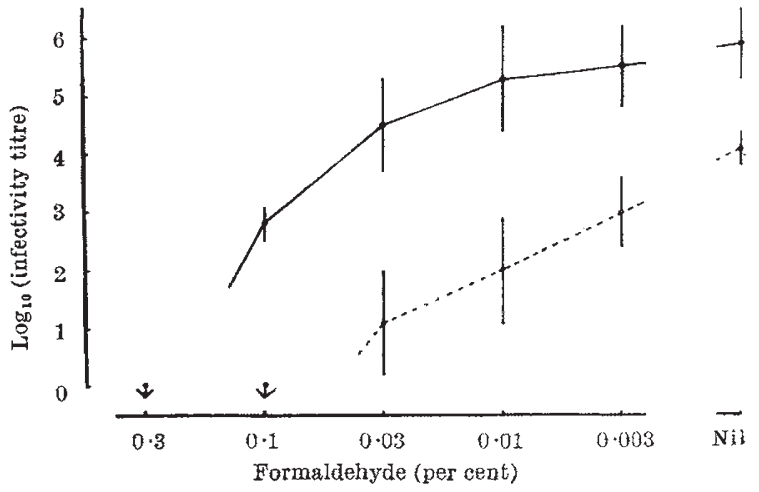

Fig. 2. Infectivity titres for the chick embryo of crude preparations of Murray latley encephalitis virus exposed to different concentrations of formaldehyde for $195 \mathrm{~min}$. at $20^{\circ} \mathrm{C}$. and of the 'RNA' derived by phenol treatment from such treated virus. Each poin is the mean value of between 4 and 10 experiments, the vertical

lines representing the standard deviation
_. infectivity of treated virus ; _ _ . infectivity of ribonucleic acid derived from treated viru 